\title{
An analytical study to determine prohibited anabolic residues in red meat tissue using LC-MS/MS system
}

\author{
Bülent NAZLI ${ }^{1,2 *}$ (D), Elmas Oktem OLGUN ${ }^{3}$, Bilal ÇAKIR ${ }^{1}$, Mehmet DEMIRCI $^{1}$
}

\begin{abstract}
Hormones used for various purposes in animal breeding are not only important for animal health but also human health and thus meat and meat products need to be checked frequently for hormone residues. As the methods of detecting hormone residues in food samples are difficult and time-consuming, the present study was conducted with the aim of fast and practical determination of prohibited anabolic agents in red meat using LC MS-MS system. For this purpose, the QuEChERS method, which is widely used in pesticide and veterinary drug residue analysis was performed as below. Accordingly, (i) more polar solvent (Acetonitrile) was used in the sample preparation step and (ii) dispersive solid-phase solution was used instead of the solid phase extraction solution in the solution cleaning step. Furthermore, (iii) different groups were injected together in a single injection to analyze different types of anabolic substances with LC-MS/MS in the multi-component analysis phase. After the validation and determination of measurement uncertainty, 20 commercially available red meat tissues were analyzed, and the findings were compared to the literature. It was concluded that the applied method was found to be fast and reliable in the detection of prohibited anabolic agents in red meat tissue.
\end{abstract}

Keywords: anabolic agents; QuEChERS method; single injection; red meat; hormone.

Practical Application: Fast and reliable determination of prohibited anabolic agents.

\section{Introduction}

Anabolic substances have been used in animal husbandry to accelerate growth, increase the meat/fat ratio or for disease treatment and increasing milk yield (Donovan, 2015; Yücel et al., 2018). Anabolic agents (anabolic androgen steroids) are substances that imitate the effects of testosterone or dihydrotestosterone, which has a more effective form, and stimulate the development of tissues by increasing protein synthesis in the cell (European Union, 2016).

Many veterinary drugs that have an anabolic effect are prohibited in the European Union. However, they can only be used in special situations in livestock as therapeutically and prophylactically, and also to increase the yield due to its ability to benefit from feed (Kinsella et al., 2009; Reig \& Toldrá, 2008; Stolker et al., 2007). Various national and international studies revealed that the presence of anabolic hormones and similar substance residues in animal-originated foods (Kadim et al., 2010; Nazli et al., 2005; Sever et al., 2012; Shankar et al., 2010; Yilmaz et al., 2007).

Anabolic agents given in the feeding period leave residues in the meat when it is not completely eliminated from the animal body and cannot be neutralized (Kicman, 2008). Meat and meat products containing anabolic residues seriously threaten the public health (León et al., 2012; Wolk, 2017). Many studies have drawn attention to the relationship of hormone residues in foods with cancer-based on epidemiological studies (Brunetti \& Manfioletti, 2019; Reig \& Toldrá, 2008). Hormone and anabolic residues can cause harmful effects including hormonal activities, nervous complications, and vascular stiffness as well as genotoxic effects (Groner \& Brown, 2017; Seo et al., 2005).

European Union published a directive (96/22/EC) about growth-promoting substances such as hormones and $\beta$-antagonists in 1996 and according to the report, the sale and usage of stilbenes and its derivatives, esters and salts, and $\beta$-antagonists on animals were forbidden, and similarly, they banned all use of thyrostatic, estrogenic, androgenic and gestagenic preparations, except for its therapeutic use in veterinary control (European Union, 1996, 2016).

Today, the prohibition of some anabolic agents has partially reduced their practical applications. However, it is a necessity to regularly control whether there are still rule-breaking applications. National residue surveillance studies in Turkey started in 2007 with pilot experiments on seafood and poultry meat. In 2011, residual monitoring regulation became mandatory and red meat products were included to the regulation in 2014 (European Union, 2002; Turkey, 2003). 
Considering the possible risks of anabolic residues to the consumer health, it is a necessity to perform reliable tests in feed, animals and foods of animal origin, as well as to develop and use appropriate validated analytical methods (European Union, 2019; Shankar et al., 2010; Zeleny et al., 2006).

In recent years, many immunological and chromatographic research methods have been developed to identify anabolic residues in foods. Immunological methods are ELISA (Enzyme-Linked Immuno Sorbent Assay), Radioimmunoassay and Multiarray biosensors. Chromatographic methods include LC-MS/MS (Liquid chromatography coupled to tandem mass spectrometry), HPTLC (High performance thin-layer chromatography) and HPLC (High performance liquid chromatography) (Noppe et al., 2008; Toldrá \& Reig, 2006). Among these, LC-MS/MS (liquid chromatography coupled to tandem mass spectrometry) analysis method, which has sensitivity and selectivity, has been widely used (Abafe et al., 2018; Hu et al., 2014; Kaufmann, 2009).

Today, studies with Elisa test kits are mostly preferred. However, in order to increase the reliability of this method, it should be verified with other methods. According to the Directive 2002/657/EC published by the European Commission, it is recommended to use LC-MS (liquid chromatography-mass spectrometry) or GCMS (gas chromatography-mass spectrometry) to verify veterinary hormone drug residue analysis (European Union, 2002).

The well-known and classical methods used to detect the presence of anabolic residues that are important for consumer health in red meat and products, are difficult and time-consuming. For this reason, faster and more practical methods are much needed for residue monitoring programs to work more reliable. Studies on modifications to the LC-MS/MS method, which is the most reliable method in this respect, are found in the literature. In these studies, it is aimed to shorten analysis times and make them more practical by modifying the sample preparation stages and LC-MS/MS device (Anastassiades et al., 2003; AguileraLuiz et al., 2011; Shao et al., 2009; Garrido Frenich et al., 2010; Gao et al., 2012; Kaufmann et al., 2014; Lehotay et al., 2007; Tang et al., 2012; Zhan et al., 2012).

The QuEChERS method is defined as a fast, easy, cheap, effective, solid and safe extraction method that allows the analysis of high numbers of pesticides of different structures in different matrices (Melo et al., 2020). The QuEChERS method is a highly flexible approach that can be modified. In laboratory conditions, modifications can be made on the existing instrumental system according to the factors such as analyte properties and matrix structure. (Xiong et al., 2015; Yang et al., 2015).

For instance, Lehotay et al. (2007) modified the method using relatively strong acetate buffering conditions and their method was approved by "AOAC Official Method 2007.01". Anastassiades et al. (2003): preferred weaker citrate buffering conditions and their method was approved as "Standard Method EN 15662 by European Committee for Standardization (CEN)". Both approved methods are widely used in routine multiple pesticide analysis today.

Similarly, some modifications can be made in the sample preparation phase of banned anabolic and they can be detected more easily and quickly with a single sample preparation. The development of such analytical methods will ensure that the National Residue Monitoring programs are carried out more healthily and will be beneficial for food safety and consumer health.

This study was carried out to obtain a more practical and faster result for the detection of prohibited anabolic in red meat tissue using the QuEChERS and LC-MS/MS method previously used in the pesticide analysis.

\section{Materials and methods}

\subsection{Material}

\section{Chemicals}

Acetonitrile (ACN), methanol, formic acid, glacial acetic acid chemicals HPLC purity was purchased from Merck (Darmstadt, Germany). Helix pomatia enzyme was obtained from Sigma Aldrich (St. Louis Missouri, USA). The pure water used in the analyzes was obtained from Milli-Q Plus system (EMD Millipore, Billerica, MA). Magnesium sulfate, sodium chloride, Supelclean TM Primary secondary amine (PSA), pure steroid, stilbene, zeranol and beta agonist standards, were procured from Sigma Aldrich (St. Louis Missouri, USA) and Dr. Ehrenstrorfer (Ausburg, Germany).

\section{Meat samples}

Organic red meat tissues used for the validation of the modified method and 20 red meat samples used for the detection of anabolic residues collected from the Istanbul markets created the material of the study.

\subsection{Method}

Sample preparation

In the preparation step of the sample, the QuEChERS, which is a common method usually performed in pesticide detection was used for anabolic detection (Stubbings \& Bigwood, 2009; Tripathy et al., 2019; Yang et al., 2015). Accordingly, the samples were treated with more acetonitrile and the extracts were cleaned by dispersive solid-phase extraction method instead of conventional solid-phase extractions (Chiesa et al., 2016; Fan et al., 2014; Luo et al., 2016; Schmidt et al., 2008; Lehotay et al., 2007; Yang et al., 2009).

Six g homogenized meat tissue was taken in a $60 \mathrm{~mL}$ centrifuge tube; after adding $10 \mathrm{~mL}$ of $0.2 \mathrm{M}$ Acetate buffer solution and vortexed for 1 minute. Then $100 \mu \mathrm{L}$ of Helix pomatia enzyme was added and incubated at $37 \pm 2{ }^{\circ} \mathrm{C}$ for 17 hours. The mixture was vortexed for 1 minute again after adding $10 \mathrm{~mL}$ of $\mathrm{ACN}$ and $4 \mathrm{~g}$ anhydrous $\mathrm{MgSO}_{4}$ and $1 \mathrm{~g}$ anhydrous $\mathrm{NaAC}$ were added and mixed for 3 minutes, then centrifuged at $4000 \mathrm{rpm}$ for 10 minutes. The supernatant was transferred into a $15 \mathrm{~mL}$ centrifuge tube, $500 \mathrm{mg}$ PSE and $500 \mathrm{mg} \mathrm{C} 18$ sorbents were added and after stirring for 3 minutes centrifuged at $4000 \mathrm{rpm}$ for 10 minutes for the second time. The supernatant in a glass centrifuge was evaporated with nitrogen till dried at $40{ }^{\circ} \mathrm{C}$ and resuspended in 
$200 \mu \mathrm{L}$ water/methanol 80/20 (v/v) and was poured into vials (Anastassiades et al., 2003; Shao et al., 2009, Lehotay et al., 2007).

\section{Preparation of standard solution}

$1000 \mu \mathrm{g} / \mathrm{L}$ stock standard solution was prepared in methanol solvent for each anabolic hormone. Subsequently, all samples were mixed with $10 \mu \mathrm{g} / \mathrm{L}$ intermediate stock solution and the whole mixture was prepared in the mobile phase by diluting to $0.5,1,1.5,2 \mu \mathrm{g} / \mathrm{L}$ (Kaufmann et al., 2008).

\section{LC-MS/MS analysis}

Four different groups containing 11 anabolic agents were injected into LC-MS/MS device with a single injection and the $\mathrm{pH}$ of the mobile phase was set up to 9 with $0.1 \mathrm{~N} \mathrm{NH}_{4} \mathrm{OH}$ (Impens et al., 2007; Rocha et al., 2019).

The chromatographic separation was carried out with a Symmetry C18 $6 \mu 2,1 \times 160 \mathrm{~mm}$ column, and $66 \%(\mathrm{v} / \mathrm{v})$ methanol and water with $\mathrm{pH} 9$ (adjusted with $0.1 \mathrm{~N} \mathrm{NH}_{4} \mathrm{OH}$ ) were used as mobile phase as isocratic flow. HPLC system with a Binary pump (Shimadzu UFLC LC-20AD model), Shimadzu autoinjector (Auto Sampler SIL-20A HT model) and column oven (CTO-20AC) system were preferred for the separation process. The column temperature was set to $40{ }^{\circ} \mathrm{C}$, the mobile phase flow rate was $0.2 \mathrm{~mL} / \mathrm{min}$ and the injection volume was $50 \mu \mathrm{L}$. Applied Biosystems MDS SCIEX 4500 Q TRAP was used for mass quantification after separation. The MS/MS detector was set to curtain gas $20 \mathrm{~mL} / \mathrm{min}$, exit potential $10 \mathrm{~V}$, ion source gas 1 and ion source gas $250 \mathrm{~mL} / \mathrm{min}$, ion spray voltage $5500 \mathrm{~V}$ and turbo spray temperature $550{ }^{\circ} \mathrm{C}$ (Di Donna et al., 2015; Hu et al., 2014; Van Bennekom et al., 2002; Yang et al., 2009).
A chromatogram of the meat sample enriched with $1 \mu \mathrm{g} / \mathrm{L}$ was presented in Figure 1.

\section{Validation}

The analytical method was validated according to EU Decision 2002/657/EC and SANTE/12682/2019 directives. Validation linearity, detection and decision limit, recovery, repeatability, reproducibility, and measurement uncertainty parameters were evaluated (European Union, 2019; Gaugain-Juhel et al., 2009; Moussa et al., 2020; Tripathy et al., 2019).

\section{Results and discussion}

At the sample preparation step, using acetonitrile in the extraction provided an increase in the recovery yield. For the extraction of the targeted molecule, many studies have been reported in enzymatic reaction with Beta Glucuronidase enzyme at a certain $\mathrm{pH}$ for $12-14$ hours at $37^{\circ} \mathrm{C}$, as well as 1 hour at $60^{\circ} \mathrm{C}$. In addition, there are studies using ethyl acetate in the phase of drawing analytes into organic phase after the enzymatic reaction there are also studies extracting with methanol (Blasco et al., 2007; Lehotay et al., 2007; Marchand et al., 2000; Souza et al., 2016; Stolker et al., 2008).

In the sample cleaning step, the usage of dispersive solidphase extraction instead of solid-phase extraction lowered the duration of sample preparation protocol by reducing solvent amount. At this stage, solid phase extraction methods containing different types of filling materials are used. While some studies were performed using a single solid phase, some studies used two or even three SPE. (Anastassiades et al., 2003; Shao et al., 2009; Blasco et al., 2007; Seo et al., 2005). Filling materials

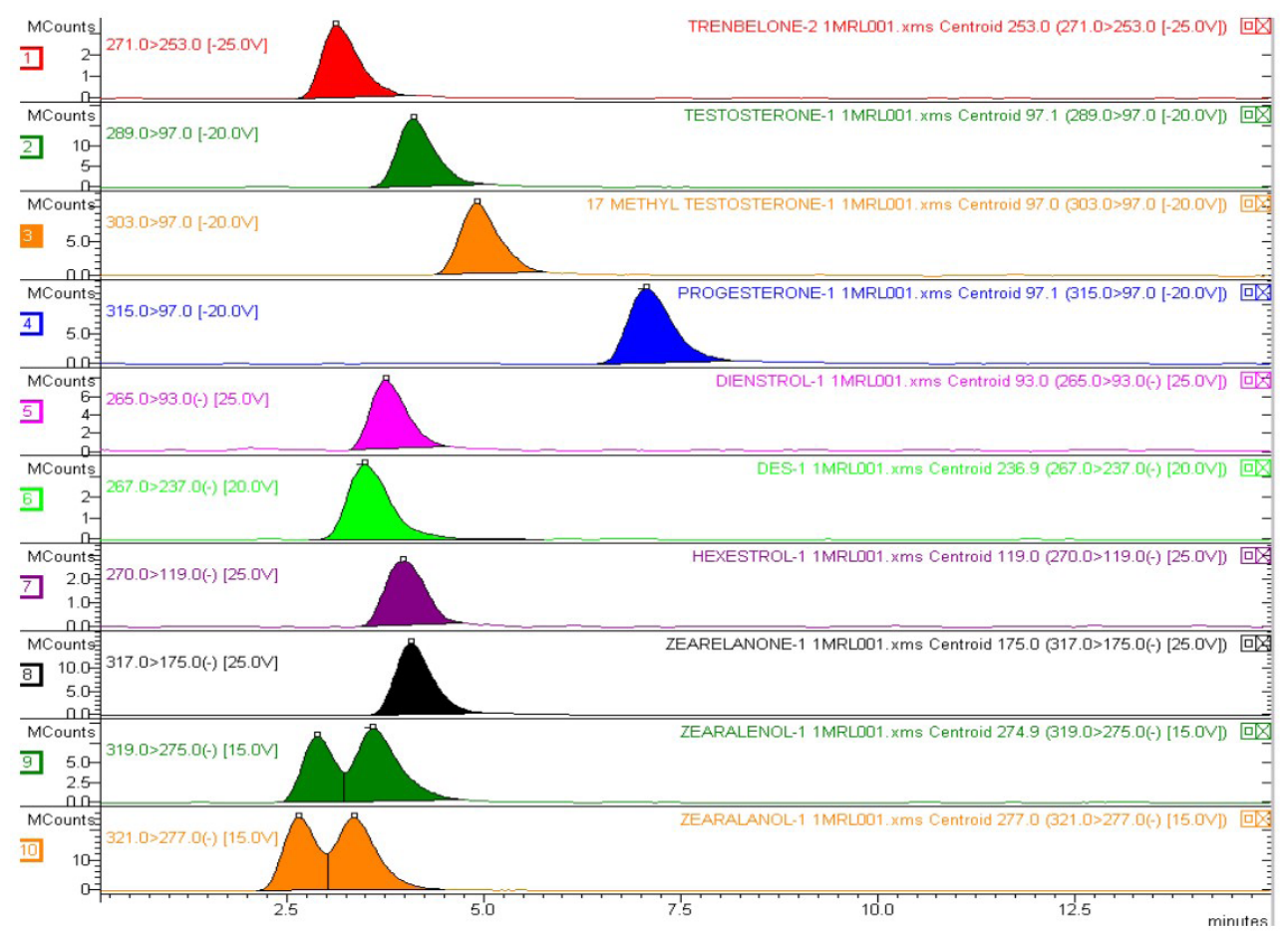

Figure 1. Chromatogram of meat sample enriched with $1 \mu \mathrm{g} / \mathrm{kg}$. 
containing $\mathrm{HLB}, \mathrm{C} 18, \mathrm{NH}_{2}$, activated carbon and molecular Imprinted polymer are commonly used (Kootstra et al., 2005; Zheng et al., 2014).

The development of a single injection method for prohibited anabolic substances injected separately under different conditions, resulted in shortening overall method duration (AguileraLuiz et al., 2008; Rocha et al., 2019; Turnipseed et al., 2008; Zhang et al., 2015). Changing the $\mathrm{pH}$ value of the mobile phase $(\mathrm{pH}$ 9) facilitated their analysis especially by increasing the sensitivity of the stilbene groups, and high abundances were obtained from the low-abundance molecules and the method reached to the desired performance limits (Impens et al., 2007).

In the validation studies, there were no interfering substances on 10 organic red meat samples for the selectivity of the method (Gaugain-Juhel et al., 2009; Tripathy et al., 2019). Validation data were given in Table 1.

In our study, the correlation factors for linearity were examined with the curves plotted in the range of $0.5-1-1.5-2 \mu \mathrm{g} / \mathrm{L}$ at 4 different concentrations. The linear measurement range for all samples showed a proportional increase with the changing concentrations, and the correlation values were found to be greater than 0.99 (Table 1 ). These results were appropriately evaluated within the acceptance limits of the directive (European Union, 2002).

López-García et al. (2018), reported that the linearity was in the range of 1 to $50 \mu \mathrm{g} / \mathrm{kg}$ for most of the target compounds in the three matrices. Correlation values were found to be higher than 0.99 for all compounds. Relative uncertainty values (RSD) were determined below $20 \%$ for all compounds by analyzing 5 control samples specific to each meat type. In our study, similar results were obtained in terms of relative uncertainty values (RSD) and correlation values of linearity in the range of 0.5 to $2.0 \mu \mathrm{g} /$ $\mathrm{kg}$ (Table 1). However, the application of the linearity studies at the lower concentrations $(0.5 \mu \mathrm{g} / \mathrm{kg})$ is of great importance for the reliability of the results.
In a related study performed by Kaufmann et al. (2008), the correlation coefficients for linearity were found to be greater than 0.99 , and the acquisition of these values was related to the preparation of standards using the internal standard method. Similarly, in another study conducted by Shao et al. (2009), 50 hormones were investigated, and the correlation coefficients were found to be higher than 0.99 .

European Commission Decision, 2002/657/EC, implementing Council Directive 96/23/EC, the acceptance criteria for accuracy and repeatability are reported between $70-120 \%$ and Repeatability Relative Standard Deviation (RSD) is less than 20\% (European Union, 2002). In our study, the standard deviation (RSD) as relative to the accuracy of the method validation was found to be $1-16 \%$ and the recovery was $100-115 \%$.

In a study conducted by Luo et al. (2016), 16 hormones were analyzed together and the RSD\% ranged between 1-8\% and the recovery was between $81.9-97.9 \%$ in the validation. In another study by Yang et al. (2015) for the determination of 26 endocrine chemicals in fish and water, the modified QuEChERS method combined with solid phase extraction and UHPLC-MS/MS was used and recovery was achieved between $69.1 \%$ and $120.5 \%$.

The results obtained in our study were found to be in agreement with the information provided by the directive and the above-mentioned literature but were considered higher than those of some studies were.

In our study, the decision limit ( $\mathrm{CC} \alpha$ ) was found to be $0.5 \mu \mathrm{g} / \mathrm{kg}$ and the detection capability $(\mathrm{CC} \beta)$ was $0.6 \mu \mathrm{g} / \mathrm{kg}$ (Table 1). These values determined by the validated method and obtained from 20 replicate studies for each anabolic were found to be superior to some studies comparing to the literature (Seo et al., 2005; Schmidt et al., 2008; Kootstra et al., 2005).

In a study conducted by Chiesa et al. (2016), skim milk samples were extracted with an organic solvent and subjected to anabolic analysis on LC-MS/MS after passing through

Table 1. Mean Values of Method Validation Parameters.

\begin{tabular}{|c|c|c|c|c|c|c|c|}
\hline Analyte & $\begin{array}{c}\text { Precursor ion, } \\
(\mathrm{m} / \mathrm{z})\end{array}$ & $\begin{array}{l}\text { Fragment ions, } \\
(\mathrm{m} / \mathrm{z})\end{array}$ & $\begin{array}{c}\text { Precision } \\
\text { (RSDr\%, } \mathrm{n}=18)\end{array}$ & $\begin{array}{c}\text { Precision } \\
\text { (RSDwR\%, } \mathrm{n}=18)\end{array}$ & $\begin{array}{c}\text { Recovery (\%) } \\
(\mathrm{n}=18)\end{array}$ & LOQ $(\mu \mathrm{g} / \mathrm{kg})$ & $r^{2}$ \\
\hline 17-alfa ethnylestradiol & 279,3 & $133,158.6$ & 12 & 16 & 85 & 1.0 & 0.997 \\
\hline 17- alfa-estradiol & 255 & 159,133 & 10 & 15 & 98 & 1.0 & 0.998 \\
\hline 17-beta estradiol & 255 & 159,133 & 10 & 15 & 98 & 1.0 & 0.998 \\
\hline diethylstilbesterol & 269,5 & 135,107 & 16 & 15 & 88 & 1.0 & 0.995 \\
\hline hexestrol & (-) 269.1 & $133,5,119$ & 10 & 17 & 99 & 1.0 & 0.994 \\
\hline progesterone & 316 & 109,97 & 16 & 11 & 101 & 1.0 & 0.993 \\
\hline 17-beta-testesterone & 290 & 97,109 & 9 & 9 & 106 & 1.0 & 0.996 \\
\hline trenbelone & 321,5 & 303 & 12 & 10 & 110 & 1.0 & 0.998 \\
\hline alfa zearalanol & 323,6 & 305,287 & 12 & 15 & 86 & 1.0 & 0.995 \\
\hline alfa zearalenol & (-) 319.3 & 159,13 & 11 & 16 & 91 & 1.0 & 0.991 \\
\hline beta zearalanol & 323,6 & 305,287 & 10 & 13 & 95 & 1.0 & 0.997 \\
\hline beta zearalenol & (-) 319.3 & 159,13 & 11 & 14 & 105 & 1.0 & 0.994 \\
\hline zearalenone & 321 & 303,189 & 16 & 18 & 86 & 1.0 & 0.998 \\
\hline
\end{tabular}

Note: linearity studies were conducted ranged in four different concentration (0.5-1.0-1.5-2.0 $\mu \mathrm{g} / \mathrm{kg})$. The highest/lowest values in validation parameters were presented in table. The validation parameters were studied in 3 different concentrations with 6 duplicates. (RSDr: Repeatability relative standard deviation, LOQ: Limit of quantitation and r2: Correlation efficiency) 
immunoaffinity columns. This method was validated according to the requirements of $2002 / 657 / \mathrm{EC}$, and CC $\alpha$ and CC $\beta$ values are found to be as $0.46-0.99 \mu \mathrm{g} / \mathrm{kg}$ and $1.06-2.56 \mu \mathrm{g} / \mathrm{kg}$, respectively.

The study of Chiesa et al. (2016) covers the method study for the detection of corticosteroid and anabolic steroids in the milk given calves. In this study, the milk was defatted and extracted with an organic solvent, then passed through the immunoaffinity columns and analyzed in LC-MS/MS. The method was validated according to 2002/657/EC requirements and CC $\alpha$ and CC $\beta$ values were found to be $0.46-0.99 \mu \mathrm{g} / \mathrm{kg}, 2.56-1.06 \mu \mathrm{g} / \mathrm{kg}$, respectively.

In the study conducted by Moussa et al. (2020) with the LC-MS/MS method for hormone detection in cattle matrices and They were determined the decision limit $(\mathrm{CC} \alpha)$ value is between $0.13-0.86 \mu \mathrm{g} / \mathrm{kg}$ and the detection capability (CC $\beta$ ) value is between $0.25-1.72 \mu \mathrm{g} / \mathrm{kg}$ for the majority of analytes.

In another study by Kootstra et al. (2005), molecularly imprinted polymers were used as solid phase extraction in an LC-MS/MS method developed for anabolic assay and the detection limit was calculated to be $1 \mu \mathrm{g} / \mathrm{kg}$.

Likewise, Shao et al. (2009), in the LC-MS/MS method developed for the analysis of 11 prohibited anabolic agents, the samples were cleaned in the solid-phase extraction columns filled with Oasis HLB, silica and aminopropyl, and injected into the system, and the validation detection limit was found to be $1 \mu \mathrm{g} / \mathrm{kg}$.

In a procedure developed for prohibited steroids in bovine, pig and poultry meats, after the samples were enzymatically broke down, cleaned on $\mathrm{C} 18$ and $\mathrm{NH}_{2}$ SPE columns and injected into LC-MS/MS; the lowest detection value was calculated as $0.5 \mu \mathrm{g} / \mathrm{kg}$ in validation (Blasco et al.,2011).

The findings obtained in these studies were close to or higher than those of our study. It was concluded that the more appropriate findings obtained in our study were shaped by increasing the sensitivity of the device and using the dispersive SPE phase.

The measurement uncertainty results of the validated method were given in Table 2. Accordingly, it was determined that while the sum of the uncertainties from the standard preparation steps was as $0.084 \%$, the uncertainty components from the sample preparation were $0.063 \%$. The sum of the uncertainties from the standard and sample preparation, the instrument stages, the recovery, repeatability, and reproducibility parameters were found to be $11-17 \%$.

Extended uncertainty values for measurement uncertainty were determined to be between $21-27 \%$ and these values were accepted as suitable because they were acceptable up to $50 \%$ for the residues. In addition, as the limits of detection were reported at $10 \mu \mathrm{g} / \mathrm{kg}$, it was considered as a good result that the uncertainty was below $30 \%$ at $1 \mu \mathrm{g} / \mathrm{kg}$ (European Union, 2010). 20 red meat samples obtained from Istanbul markets were analyzed with modified and validated LC-MS/MS method after determination of measurement uncertainty. As a result, $1.1-6.7 \mu \mathrm{g} / \mathrm{kg}$ of testosterone was found in 6 samples and $0.90-4.3 \mu \mathrm{g} / \mathrm{kg}$ of DES was found in 4 samples. Zeranol and its metabolites and beta agonist residues were not detected in any of the samples analyzed.

In Turkey, some studies using ELISA method for the detection of anabolic agents in meat and products are available. Nazli et al. (2005), studied on 30 meat and 30 meat products sold in the Istanbul region; while all samples found to be contained zeranol; $80 \%$ of all samples had trenbolone and 35\% had diethylstilbestrol. Yilmaz et al. (2007) reported a study on 155 beef samples, zeranol was detected in 18 samples, testosterone in 6 samples, trenbolone acetate in 7 samples, DES in 1 sample and $17 \beta$-estradiol in 22 samples.

Mor et al. (2011) investigated the presence of zeranol and trenbolone in the liver, kidney and meat samples of cattle bred in Burdur region. In total 30 meat samples examined, zeranol was detected as $100-150 \mu \mathrm{g} / \mathrm{kg}$ in 4 samples, $151-200 \mu \mathrm{g} / \mathrm{kg}$ in 5 samples, $201-500 \mu \mathrm{g} / \mathrm{kg}$ in 2 samples; on the other hand trenbolone was detected as $50-100 \mu \mathrm{g} / \mathrm{kg}$ in 30 samples, $100-150 \mu \mathrm{g} / \mathrm{kg}$ in 21 samples and $151-200 \mu \mathrm{g} / \mathrm{kg}$ in 6 samples.

Sever et al. (2012) reported that the presence of Beta Estradiol in 4 samples, diethylstilbestrol in 4 samples, and zeranol in 8 samples of 16 beef samples in Erzurum region. Similarly,

Table 2. Mean Values of Measurement Uncertainty $(n=20)$.

\begin{tabular}{cccccccc}
\hline Anabolic agent & $\begin{array}{c}\text { Std. } \\
\text { Preparation }\end{array}$ & $\begin{array}{c}\text { Sample } \\
\text { Preparation }\end{array}$ & Uco & Sr & RSDr & RSD $\sqrt{10}$ & Uncertainty \\
\hline Clenbuterol & $8,30 \mathrm{E}-02$ & $6,30 \mathrm{E}-02$ & $9,02 \mathrm{E}-06$ & $6,70 \mathrm{E}-04$ & $2,78 \mathrm{E}-02$ & $9,93 \mathrm{E}-03$ & 11 \\
Uncertainty
\end{tabular}

Note: Std: Standart, Uco: Measurement uncertainty, Sr: Repeatibilty limit value, RSDr: Repeatibility relative standart devitiation, RSD $\sqrt{ } 10$ : Relative standart devitiation 
Yücel et al. (2018) examined 80 beef samples by ELISA from Van, Turkey and were detected trenbolone in 37 (46.25\%), zeranol in $34(42.5 \%)$, testosterone in $22(27.5 \%)$ and DES in $11(13.75 \%)$.

Due to the difficulties of confirmation and the possibility of finding false detected substitute of ELISA method, it is possible that some of the published studies might find prohibited agents in the samples on the market. When more selective in situ analysis such as LC-MS/MS performed, it will be seen that the frequency of detection of prohibited hormones is lower than expected.

In analyzes made with real samples of our study, the detection of testosterone in some samples might be considered normal in terms of the age and sex of the animals. However, the presence of DES in the samples indicated the presence of illegal practices and therefore could cause public health risks.

\section{Conclusion}

According to the data reported above, the applications in our study were sum up as using of acetonitrile in the sample extraction process, using of dispersive solid phase instead of the classical solid phase in the sample cleaning process, as well as introducing different sample groups into the system with a single injection. Accordingly, LC-MS/MS method, which was validated, and calculated measurement uncertainty was found to be practical and give reliable results in anabolic detection in a shorter time. For this reason, it was concluded that the present method could be used safely in the detection of prohibited anabolic substances in meat and related products.

On the other hand, while the unit cost of the classical method analysis was $\$ 30$, the cost of the developed method was calculated as $\$ 15$. In terms of analysis time, while 20 samples could be studied in the classical method almost in two days, the sample number reached 50 with the new method for the same period. For this reason, it could be mentioned that this method was found to be less costly and faster than those of the classical methods. In this study, a specific, sensitive, and reliable single injection multiple residue LC-MS/MS method was used to simultaneously identifies and measures 11 natural/synthetic anabolic substances in red meat tissue. The data exhibited satisfactory, sensitivity and accuracy according to the criteria set by European Union regulations (EC). The analytical method in this study, showed that it met the required sensitivity of $1-10 \mu \mathrm{g} / \mathrm{kg}$ set by the National Reference Laboratories. All calculated CC $\alpha$ and CC $\beta$ values were considerably lower than these levels. Therefore, it was considered that the present method could be useful for official residue control analysis. It is important to conducted analytical studies that will make it possible to identify prohibited anabolic agents with a single sample preparation more easily, quickly and cheaply. In this way, National Residue Monitoring programs will be carried out more healthily and thus food safety and consumer health will be protected.

\section{Highlights}

The single injection multiple residue LC-MS/MS method was used to simultaneously determination of prohibited anabolic agents in red meat.
The present study provided more reliable results comparing to the similar studies conducted with different techniques in Turkey.

A quick, less costly and more reliable method for determination of anabolic agents in red meat tissue was successfully performed.

\section{References}

Abafe, O. A., Gatyeni, P. M., \& Chokwe, T. (2018). Development and validation of a confirmatory method for the determination of stilbene estrogens in ostrich serum. Food Additives \& Contaminants: Part A, 35(3), 458-466. http://dx.doi.org/10.1080/19440049.2017.1411 617. PMid:29210606.

Aguilera-Luiz, M. M., Plaza-Bolaños, P., Romero-González, R., Martínez Vidal, J. L., \& Frenich, A. G. (2011). Comparison of the efficiency of different extraction methods for the simultaneous determination of mycotoxins and pesticides in milk samples by ultra high-performance liquid chromatography-tandem mass spectrometry. Analytical and Bioanalytical Chemistry, 399(8), 2863-2875. http://dx.doi.org/10.1007/ s00216-011-4670-7. PMid:21286690.

Aguilera-Luiz, M. M., Vidal, J. L. M., Romero-González, R., \& Frenich, A. G. (2008). Multi-residue determination of veterinary drugs in milk by ultra-high-pressure liquid chromatography-tandem mass spectrometry. Journal of Chromatography. A, 1205(1-2), 10-16. http://dx.doi.org/10.1016/j.chroma.2008.07.066. PMid:18752803.

Anastassiades, M., Lehotay, S. J., Štajnbaher, D., \& Schenck, F. J. (2003). Fast and easy multiresidue method employing acetonitrile extraction/partitioning and "dispersive solid-phase extraction" for the determination of pesticide residues in produce. Journal of AOAC International, 86(2), 412-431. http://dx.doi.org/10.1093/ jaoac/86.2.412. PMid:12723926.

Blasco, C., Masia, A., Morillas, F. G., \& Picó, Y. (2011). Comparison of the effectiveness of recent extraction procedures for antibiotic residues in bovine muscle tissues. Journal of AOAC International, 94(3), 9911003. http://dx.doi.org/10.1093/jaoac/94.3.991. PMid:21797029.

Blasco, C., Van Poucke, C., \& Van Peteghem, C. (2007). Analysis of meat samples for anabolic steroids residues by liquid chromatography/ tandem mass spectrometry. Journal of Chromatography A, 1154(12), 230-239. http://dx.doi.org/10.1016/j.chroma.2007.03.090. PMid:17459396.

Brunetti, A., \& Manfioletti, G. (2019). Hormone receptors and breast cancer. Frontiers in Endocrinology, 10, 205. http://dx.doi.org/10.3389/ fendo.2019.00205. PMid:31001204.

Chiesa, L. M., Nobile, M., Biolatti, B., Pavlovic, R., Panseri, S., Cannizzo, F. T., \& Arioli, F. (2016). Detection of selected corticosteroids and anabolic steroids in calf milk replacers by liquid chromatographyelectrospray ionisation-Tandem mass spectrometry. Food Control, 61, 196-203. http://dx.doi.org/10.1016/j.foodcont.2015.09.028.

Di Donna, L., Benabdelkamel, H., Taverna, D., Indelicato, S., Aiello, D., Napoli, A., Sindona, G., \& Mazzotti, F. (2015). Determination of ketosteroid hormones in meat by liquid chromatography tandem mass spectrometry and derivatization chemistry. Analytical and Bioanalytical Chemistry, 407(19), 5835-5842. http://dx.doi.org/10.1007/ s00216-015-8772-5. PMid:26014285.

Donovan, C. (2015). If FDA does not regulate food, who will? A study of hormones and antibiotics in meat production. American Journal of Law \& Medicine, 41(2-3), 459-482. http://dx.doi. org/10.1177/0098858815591528. PMid:26591829.

European Union, Unit-Management of Scientific Committees II. (2016, April 30). Opinion of the scientific commitee on veterinary measures relating to public health: assessment of potential risks 
to human health from hormon residues in bovine meat and meat products. Official Journal of the European Union.

European Union. (1996, May 23). Council Directive 96/22EC of 29 April 1996 concerning the prohibition on the use in stock farming of certain substances having a hormonal other thyrostatic action and of beta-agonist, and repealing Directives 81/602. Official Journal of the European Union, L 125/3. Retrieved from http://www.bfr.bund. de/cm/209/96_22_ec.pdf

European Union. (2002, August 17). Commission Decision 2002/657/ EC of 12 August 2002 implementing Council Directive 96/23/EC concerning the performance of analytical methods and the interpretation of results. Official Journal of the European Communities, L 221/8.

European Union. (2010, January 20). Commission Regulation (EU) No 37/2010 of 22 December 2009 on pharmacologically active substances and their classification regarding maximum residue limits in foodstuffs of animal origin. Official Journal of the European Union, L 15/1.

European Union. (2019) European Commission Decision SANTE/12682/2019 method validation and quality control procedures for pesticide residues analysis in food and feed. Official Journal of the European Union. Retrieved from https://www.eurl-pesticides.eu/userfiles/file/ EurlALL/AqcGuidance_SANTE_2019_12682.pdf

Fan, Y. B., Yin, Y. M., Jiang, W. B., Chen, Y. P., Yang, J. W., Wu, J., \& Xie, M. X. (2014). Simultaneous determination of ten steroid hormones in animal origin food by matrix solid-phase dispersion and liquid chromatography-electrospray tandem mass spectrometry. Food Chemistry, 142, 170-177. http://dx.doi.org/10.1016/j. foodchem.2013.06.104. PMid:24001828.

Gao, F., Zhao, Y., Shao, B., \& Zhang, J. (2012). Determination of residues of pesticides and veterinary drugs in milk by ultra performance liquid chromatography coupled with quadrupole-time of flight mass spectrometry. Se Pu, 30(6), 560-567. http://dx.doi.org/10.3724/ SP.J.1123.2012.02021. PMid:23016288.

Garrido Frenich, A., Aguilera-Luiz, M. M., Martínez Vidal, J. L., \& Romero-González, R. (2010). Comparison of several extraction techniques for multiclass analysis of veterinary drugs in eggs using ultra-high pressure liquid chromatography-tandem mass spectrometry. Analytica Chimica Acta, 661(2), 150-160. http:// dx.doi.org/10.1016/j.aca.2009.12.016. PMid:20113729.

Gaugain-Juhel, M., Delépine, B., Gautier, S., Fourmond, M. P., Gaudin, V., Hurtaud-Pessel, D., Verdon, E., \& Sanders, P. (2009). Validation of a liquid chromatography-tandem mass spectrometry screening method to monitor 58 antibiotics in milk: a qualitative approach. Food Additives and Contaminants, 26(11), 1459-1471. http://dx.doi. org/10.1080/02652030903150575. PMid:19693719.

Groner, A. C., \& Brown, M. (2017). Role of steroid receptor and coregulator mutations in hormone-dependent cancers. The Journal of Clinical Investigation, 127(4), 1126-1135. http://dx.doi.org/10.1172/ JCI88885. PMid:28368289.

Hu, W. Y., Kang, X. J., Zhang, C., Yang, J., Ling, R., Liu, E. H., \& Li, P. (2014). Packed-fiber solid-phase extraction coupled with high performance liquid chromatography-tandem mass spectrometry for determination of diethylstilbestrol, hexestrol, and dienestrol residues in milk products. Journal of Chromatography. B, Analytical Technologies in the Biomedical and Life Sciences, 957, 7-13. http:// dx.doi.org/10.1016/j.jchromb.2014.02.036. PMid:24636894.

Impens, S., Van Loco, J., Degroodt, J. M., \& De Brabander, H. (2007). A downscaled multi-residue strategy for detection of anabolic steroids in bovine urine using gas chromatography tandem mass spectrometry (GC-MS3). Analytica Chimica Acta, 586(1-2), 43-48. http://dx.doi. org/10.1016/j.aca.2006.09.047. PMid:17386695.
Kadim, I. T., Mahgoub, O., Al-Marzooqi, W., Al-Maqbaly, R., Annamali, K., \& Khalaf, S. K. (2010). Enzyme-Linked Immunosorbent Assay for Screening Antibiotic And Hormone Residues In Broiler Chicken Meat In The Sultanate Of Oman. Journal of Muscle Foods, 21(2), 243-254. http://dx.doi.org/10.1111/j.1745-4573.2009.00179.x.

Kaufmann, A. (2009). Validation of multiresidue methods for veterinary drug residues; related problems and possible solutions. Analytica Chimica Acta, 637(1-2), 144-155. http://dx.doi.org/10.1016/j. aca.2008.09.033. PMid:19286023.

Kaufmann, A., Butcher, P., Maden, K., \& Widmer, M. (2008). Quantitative multiresidue method for about 100 veterinary drugs in different meat matrices by sub $2-\mu \mathrm{m}$ particulate high-performance liquid chromatography coupled to time of flight mass spectrometry. Journal of Chromatography. A, 1194(1), 66-79. http://dx.doi.org/10.1016/j. chroma.2008.03.089. PMid:18485352.

Kaufmann, A., Butcher, P., Maden, K., Walker, S., \& Widmer, M. (2014). Multi-residue quantification of veterinary drugs in milk with a novel extraction and cleanup technique: salting out supported liquid extraction (SOSLE). Analytica Chimica Acta, 820, 56-68. http:// dx.doi.org/10.1016/j.aca.2014.02.038. PMid:24745738.

Kicman, A. T. (2008). Pharmacology of anabolic steroids. British Journal of Pharmacology, 154(3), 502-521. http://dx.doi.org/10.1038/ bjp.2008.165. PMid:18500378.

Kinsella, B., O’Mahony, J., Malone, E., Moloney, M., Cantwell, H., Furey, A., \& Danaher, M. (2009). Current trends in sample preparation for growth promoter and veterinary drug residue analysis. Journal of Chromatography. A, 1216(46), 7977-8015. http://dx.doi.org/10.1016/j. chroma.2009.09.005. PMid:19782992.

Kootstra, P. R., Kuijpers, C. J. P. F., Wubs, K. L., Van Doorn, D., Sterk, S. S., Van Ginkel, L. A., \& Stephany, R. W. (2005). The analysis of beta-agonists in bovine muscle using molecular imprinted polymers with ion trap LCMS screening. Analytica Chimica Acta, 529(1-2), 75-81. http://dx.doi.org/10.1016/j.aca.2004.09.053.

Lehotay, S. J., O’Neil, M., Tully, J., García, A. V., Contreras, M., Mol, H., Heinke, V., Anspach, T., Lach, G., Fussell, R., Mastovska, K., Poulsen, M. E., Brown, A., Hammack, W., Cook, J. M., Alder, L., Lindtner, K., Vila, M. G., Hopper, M., de Kok, A., Hiemstra, M., Schenck, F., Williams, A., \& Parker, A. (2007). Determination of pesticide residues in foods by acetonitrile extraction and partitioning with magnesium sulfate: collaborative study. Journal of AOAC International, 90(2), 485-520. http://dx.doi.org/10.1093/jaoac/90.2.485. PMid:17474521.

León, N., Roca, M., Igualada, C., Martins, C. P., Pastor, A., \& Yusá, V. (2012). Wide-range screening of banned veterinary drugs in urine by ultra high liquid chromatography coupled to high-resolution mass spectrometry. Journal of Chromatography. A, 1258, 55-65. http://dx.doi.org/10.1016/j.chroma.2012.08.031. PMid:22939377.

López-García, M., Romero-González, R., \& Garrido Frenich, A. (2018). Determination of steroid hormones and their metabolite in several types of meat samples by ultra high performance liquid chromatography_Orbitrap high resolution mass spectrometry. Journal of Chromatography. A, 1540, 21-30. http://dx.doi.org/10.1016/j. chroma.2018.01.052. PMid:29397061.

Luo, G., Li, Y., \& Bao, J. J. (2016). Development and application of a high-throughput sample cleanup process based on 96-well plate for simultaneous determination of 16 steroids in biological matrices using liquid chromatography-triple quadrupole mass spectrometry. Analytical and Bioanalytical Chemistry, 408(4), 1137-1149. http:// dx.doi.org/10.1007/s00216-015-9213-1. PMid:26738495.

Marchand, P., Le Bizec, B., Gade, C., Monteau, F., \& André, F. (2000). Ultra trace detection of a wide range of anabolic steroids in meat by gas chromatography coupled to mass spectrometry. Journal of 
Chromatography. A, 867(1-2), 219-233. http://dx.doi.org/10.1016/ S0021-9673(99)01114-0. PMid:10670723.

Melo, M. G., Carqueijo, A., Freitas, A., Barbosa, J., \& Silva, A. S. (2020). Modified QuEChERS extraction and HPLC-MS/MS for simultaneous determination of 155 pesticide residues in rice (Oryza sativa L.). Foods, 9(1), 18. http://dx.doi.org/10.3390/foods9010018. PMid:31878165.

Mor, F., Şahindokuyucu, F., Kav, K., \& Köker, A. (2011). Sı̆̆ırların doku örneklerinde zeranol ve trenbolon kalıntılarının belirlenmesi. Eurasian Journal of Veterinary Sciences, 27(4), 236-239.

Moussa, F., Mokh, S., Doumiati, S., Barboni, B., Bernabò, N., \& Al Iskandarani, M. (2020). LC-MS/MS method for the determination of hormones: validation, application and health risk assessment in various bovine matrices. Food and Chemical Toxicology, 138, 111204. http://dx.doi.org/10.1016/j.fct.2020.111204. PMid:32081729.

Nazli, B., Çolak, H., Aydin, A., \& Hampikyan, H. (2005). The presence of some anabolic residues in meat and meat products sold in Istanbul. Turkish Journal of Veterinary and Animal Sciences, 29(3), 691-699.

Noppe, H., Le Bizec, B., Verheyden, K., \& De Brabander, H. F. (2008). Novel analytical methods for the determination of steroid hormones in edible matrices. Analytica Chimica Acta, 611(1), 1-16. http:// dx.doi.org/10.1016/j.aca.2008.01.066. PMid:18298962.

Reig, M., \& Toldrá, F. (2008). Veterinary drug residues in meat: Concerns and rapid methods for detection. Meat Science, 78(1-2), 60-67. http://dx.doi.org/10.1016/j.meatsci.2007.07.029. PMid:22062096.

Rocha, D. G., Lana, M. A. G., Augusti, R., \& Faria, A. F. (2019). Simultaneous identification and quantitation of 38 hormonally growth promoting agent residues in bovine muscle by a highly sensitive HPLC-MS/MS method. Food Analytical Methods, 12(9), 1914-1926. http://dx.doi.org/10.1007/s12161-019-01507-6.

Schmidt, K., Stachel, C., \& Gowik, P. (2008). Development and inhouse validation of an LC-MS/MS method for the determination of stilbenes and resorcylic acid lactones in bovine urine. Analytical and Bioanalytical Chemistry, 391(4), 1199-1210. http://dx.doi. org/10.1007/s00216-008-1943-x. PMid:18363048.

Seo, J., Kim, H. Y., Chung, B. C., \& Hong, J. (2005). Simultaneous determination of anabolic steroids and synthetic hormones in meat by freezing-lipid filtration, solid-phase extraction and gas chromatography-mass spectrometry. Journal of Chromatography. A, 1067(1-2), 303-309. http://dx.doi.org/10.1016/j.chroma.2004.12.063. PMid:15844536.

Sever, E., Okumuș, B., \& Ince, S. (2012). Investigation of residual $17 \beta$-estradiol, diethylstilbestrol, and zeranol in red meat sold in Erzurum Province, Turkey. Kafkas Üniversitesi Veteriner Fakültesi Dergisi, 18(2), 267-272.

Shankar, B. P., Manjunatha Prabhu, B. H., Chandan, S., Ranjith, D., \& Shivakumar, V. (2010). Rapid methods for detection of veterinary drug residues in meat. Veterinary World, 3(5), 241-246. http://dx.doi. org/10.5455/vetworld.2010.241-246.

Shao, B., Jia, X., Zhang, J., Meng, J., Wu, Y., Duan, H., \& Tu, X. (2009). Multi-residual analysis of $16 \beta$-agonists in pig liver, kidney and muscle by ultra performance liquid chromatog raphy tandem mass spectrometry. Food Chemistry, 114(3), 1115-1121. http://dx.doi. org/10.1016/j.foodchem.2008.10.063.

Souza, R., Pareja, L., Cesio, M. V., \& Heinzen, H. (2016). Development of a straightforward and cheap ethyl acetate based method for the simultaneous determination of pesticides and veterinary drugs residues in bovine liver and muscle. Chromatographia, 79(17-18), 1101-1112. http://dx.doi.org/10.1007/s10337-016-3026-Z.

Stolker, A. A. M., Rutgers, P., Oosterink, E., Lasaroms, J. J. P., Peters, R. J. B., Van Rhijn, J. A., \& Nielen, M. W. F. (2008). Comprehensive screening and quantification of veterinary drugs in milk using UPLCToF-MS. Analytical and Bioanalytical Chemistry, 391(6), 2309-2322. http://dx.doi.org/10.1007/s00216-008-2168-8. PMid:18491081.

Stolker, A. A. M., Zuidema, T., Nielen, M. W. F., \& Nielen, M. W. F. (2007). Residue analysis of veterinary drugs and growth-promoting agents. Trends in Analytical Chemistry, 26(10), 967-979. http://dx.doi. org/10.1016/j.trac.2007.09.008.

Stubbings, G., \& Bigwood, T. (2009). The development and validation of a multiclass liquid chromatography tandem mass spectrometry (LC-MS/MS) procedure for the determination of veterinary drug residues in animal tissue using a QuEChERS (QUick, Easy, CHeap, Effective, Rugged and Safe) approach. Analytica Chimica Acta, 637(1-2), 68-78. http://dx.doi.org/10.1016/j.aca.2009.01.029. PMid:19286014.

Tang, Y. Y., Lu, H. F., Lin, H. Y., Shih, Y. C., \& Hwang, D. F. (2012). Multiclass analysis of 23 veterinary drugs in milk by ultraperformance liquid chromatography-electrospray tandem mass spectrometry. Journal of Chromatography. B, Analytical Technologies in the Biomedical and Life Sciences, 881-882, 12-19. http://dx.doi.org/10.1016/j. jchromb.2011.11.005. PMid:22204873.

Toldrá, F., \& Reig, M. (2006). Methods for rapid detection of chemical and veterinary drug residues in animal foods. Trends in Food Science \& Technology, 17(9), 482-489. https://doi.org/10.1016/j.tifs.2006.02.002.

Tripathy, V., Sharma, K. K., Yadav, R., Devi, S., Tayade, A., Sharma, K., Pandey, P., Singh, G., Patel, A. N., Gautam, R., Gupta, R., Kalra, S., Shukla, P., Walia, S., \& Shakil, N. A. (2019). Development, validation of QuEChERS-based method for simultaneous determination of multiclass pesticide residue in milk, and evaluation of the matrix effect. Journal of Environmental Science and Health. Part. B, Pesticides, Food Contaminants, and Agricultural Wastes, 54(5), 394-406. http:// dx.doi.org/10.1080/03601234.2019.1574169. PMid:30755093.

Turkey. (2003, Haziran 19). Gıda Değeri Olan Hayvanlara Uygulanması Yasaklanan ve Belli Şartlara Bağlanan Hormon ve Benzeri Maddeler Hakkında Tebliğ. T.C. Tarım ve Köyişleri Bakanlığı, Koruma ve Kontrol Genel Müdürlüğü, Tebliğ No: 2003/18. T.C. Resmi Gazete.

Turnipseed, S. B., Andersen, W. C., Karbiwnyk, C. M., Madson, M. R., \& Miller, K. E. (2008). Multi-class, multi-residue liquid chromatography/ tandem mass spectrometry screening and confirmation methods for drug residues in milk. Rapid Communications in Mass Spectrometry, 22(10), 1467-1480. http://dx.doi.org/10.1002/rcm.3532. PMid:18412094.

Van Bennekom, E. O., Brouwer, L., Laurant, E. H. M., Hooijerink, H., \& Nielen, M. W. F. (2002). Confirmatory analysis method for zeranol, its metabolites and related mycotoxins in urine by liquid chromatography-negative ion electrospray tandem mass spectrometry. Analytica Chimica Acta, 473(1-2), 151-160. http://dx.doi.org/10.1016/ S0003-2670(02)00975-3.

Wolk, A. (2017). Potential health hazards of eating red meat. Journal of Internal Medicine, 281(2), 106-122. http://dx.doi.org/10.1111/ joim.12543. PMid:27597529.

Xiong, L., Gao, Y. Q., Li, W. H., Yang, X. L., \& Shimo, S. P. (2015). Simple and sensitive monitoring of $\beta 2$-agonist residues in meat by liquid chromatography-tandem mass spectrometry using a QuEChERS with preconcentration as the sample treatment. Meat Science, 105, 96-107. http://dx.doi.org/10.1016/j.meatsci.2015.03.013. PMid:25828164.

Yang, M., Ma, Y., Gui, W., Ren, Y., Zhu, G., \& Liu, Y. (2015). Determination of 26 endocrine disrupting chemicals in fish and water using modified QuEChERS combined with solid-phase extraction and UHPLC-MS/MS. Analytical Methods, 7(19), 8418-8431. http:// dx.doi.org/10.1039/C5AY01082A.

Yang, Y., Shao, B., Zhang, J., Wu, Y., \& Duan, H. (2009). Determination of the residues of 50 anabolic hormones in muscle, milk and liver by very-high-pressure liquid chromatography-electrospray 
ionization tandem mass spectrometry. Journal of Chromatography. B, Analytical Technologies in the Biomedical and Life Sciences, 877(5-6), 489-496. http://dx.doi.org/10.1016/j.jchromb.2008.12.054. PMid:19147414.

Yllmaz, D., Durmaz, G., \& Oz, B. (2007). The presence of some anabolic residues in beef meats. In Proceedings of the 5th International Congress on Food Technology Greece "Consumer Protection through Food Process Improvement \& Innovation in The World" (pp. 502505). Van, Turkey.

Yücel, U. M., Nurhayat, A., İşleyici, Ö., \& Türel, İ. (2018). Determınatıon of some anabolic hormone residues in cattle meat consumption in Van, Turkey. International Journal of Advanced Research, 6(8), 129-139. http://dx.doi.org/10.21474/IJAR01/7499.

Zeleny, R., Ulberth, F., Gowik, P., Polzer, J., van Ginkel, L. A., \& Emons, H. (2006). Developing new reference materials for effective veterinary drug-residue testing in food-producing animals. Trends in Analytical Chemistry, 25(9), 927-936. http://dx.doi.org/10.1016/j. trac.2006.04.011.
Zhan, J., Yu, X. J., Zhong, Y. Y., Zhang, Z. T., Cui, X. M., Peng, J. F., Feng, R., Liu, X. T., \& Zhu, Y. (2012). Generic and rapid determination of veterinary drug residues and other contaminants in raw milk by ultra performance liquid chromatography-tandem mass spectrometry. Journal of Chromatography. B, Analytical Technologies in the Biomedical and Life Sciences, 906, 48-57. http://dx.doi.org/10.1016/j. jchromb.2012.08.018. PMid:22959038.

Zhang, Y., Li, X., Liu, X., Zhang, J., Cao, Y., Shi, Z., \& Sun, H. (2015). Multi-class, multi-residue analysis of trace veterinary drugs in milk by rapid screening and quantification using ultra-performance liquid chromatography-quadrupole time-of-flight mass spectrometry. Journal of Dairy Science, 98(12), 8433-8444. http://dx.doi.org/10.3168/ jds.2015-9826. PMid:26506545.

Zheng, H. B., Mo, J. Z., Zhang, Y., Gao, Q., Ding, J., Yu, Q. W., \& Feng, Y. Q. (2014). Facile synthesis of magnetic molecularly imprinted polymers and its application in magnetic solid phase extraction for fluoroquinolones in milk samples. Journal of Chromatography A, 1329, 17-23. http://dx.doi.org/10.1016/j.chroma.2013.12.083. PMid:24418234. 